\title{
PERBANDINGAN AKTIVITAS ANTIOKSIDAN EKSTRAK ETANOL DAUN SIRSAK (Annona muricata L.) BERDASARKAN TEMPAT TUMBUH DENGAN METODE PEREDAMAN DPPH
}

\author{
Aminah $^{1)}$, St. Maryam, Muzakkir Baits, Ummi Kalsum \\ ${ }^{1)}$ Aminah.aminah@umi.ac.id
}

\begin{abstract}
Antioxidant activity assay has been conducted in order to determine the comparison of the antioxidant activity contained in the ethanol extract of the soursop leaves (Annona muricata L.) from Makassar, north Mamuju and Jeneponto. The amount of antioxidant activity obtained by testing against free radical DPPH (1,1-Diphenyl-2picryl Hydrazyl) at concentrations of 10,20,30, 40 dan 50 ppm with 96\% ethanol. The testing was done with the addition of $1 \mathrm{~mL}$ of the test solution with $4 \mathrm{~mL}$ DPPH $35 \mathrm{ppm}$. The absorbance of free radical activity was measured by UV-Vis spectrophotometer at the wavelength $515 \mathrm{~nm}$ and the IC50 value was calculated based on the absorbance data. The calculations showed that the soursop leaves from Makassar, North Mamuju, and Jeneponto had the IC50 value of $1.380 \mu \mathrm{g} / \mathrm{mL}, 1.512$, and 1.420 respectively. The results showed that the samples came from Makassar had a higher antioxidant activity.
\end{abstract}

Keyword: Antioxidant, ethanol extract of soursop leaves (Annona muricata L.), DPPH, UV-Vis spectrophotometry.

\section{PENDAhuluan}

Penyakit merupakan suatu kondisi dimana terdapat keadaan tubuh yang abnormal. Akhir-akhir ini masyarakat banyak melirik pengobatan tradisional dengan menggunakan bahan baku tanaman herbal sebagai alternatif untuk mencegah maupun menanggulangi berbagai keluhan penyakit yang terjadi. Salah satu contoh tanaman trandisional yang digunakan untuk mengobati penyakit adalah daun sirsak (Annona muricata L.) (Haryati, 2005).

Daun sirsak (Annona muricata L.) berasal dari Amerika tengah dan daerah Karibia. Sirsak memerlukan suhu tropis yang hangat dan lembab untuk dapat tumbuh dengan baik. Sirsak juga dapat tumbuh didataran rendah tropis hingga ketinggian $1000 \mathrm{~m}$, kandungan fitiokimia dalam sirsak diketahui memiliki sifat antikanker yang selektif. Senyawa acetogenin dilaporkan dapat membunuh sel kanker dengan cara menghambat produksi ATP sel kanker tersebut (Zuhud evrizal, 2011). Selain kandungan acetogenin yang bersifat antikanker, juga terdapat kandungan senyawa fenolik alam yang potensial sebagai antioksidan dan mempunyai bioaktivitas sebagai obat (Suharyadi, 2014).

Antioksidan adalah senyawa yang bertugas untuk menetralisir peningkatan radikal bebas, melindungi sel dari efek toksik yang dihasilkan serta berkontribusi dalam pencegahan penyakit-penyakit. Selama ini antioksidan sintetik sering digunakan karena dapat menetralkan radikal bebas namun dapat menimbulkan efek toksik. Hal tersebut membuat para peneliti semakin berminat meneliti antioksidan alami terutama yang berasal dari tanaman karena lebih aman daripada antioksidan sintetik dan mempunyai manfaat luas dibidang pengawetan pangan, kesehatan, kosmetik dan pencegahan penyakit yang disebabkan oleh radikal bebas (Sidik, 1997).

Jenis tanaman sirsak mudah dibudidayakan pada semua jenis lahan, baik itu dilahan perkebunan, daerah tanggul dipinggiran bantaran sungai, daerah pematang sawah, daerah hutan-hutan ringan, maupun dibudidayakan dihalaman rumah. Jenis tanah yang cocok bagi pertumbuhan dan perkembangan tanaman sirsak adalah jenis tanah merah, lempung berpasir, dan tanah liat cokelat dengan kandungan humus dan berstektur tanah gembur. Kecukupan air dibawah akar tanaman ini penting diperhatikan, meskipun tanaman ini tidak begitu sulit memperoleh air yang sudah dicadangkan dalam tumbuhan ini sendiri. Pada musim kering atau kemarau, tanaman ini praktis mampu bertahan hidup (Radi, 2002).

Daerah Mamuju Utara merupakan daerah hutan-hutan ringan Berdasarkan data geologi di daerah ini dapat digolongkan beberapa jenis tanah salah satunya adalah tanah alluvial atau tanah endapan merupakan tanah yang terbentuk dari lumpur dan pasir halus biasanya terjadi pada daerah-daerah dataran rendah, tanah ini dapat digunakan sebagai lahan pertanian dan sawah. Keadaan iklim di kabupaten Mamuju Utara tidak memiliki perbedaan dengan daerah lain di Indonesia yang hanya dikenal memiliki dua musim yaitu musim kemarau dan penghujanan. Daerah Makassar memiliki jenis tanah batuan sehingga perkembangan ditentukan oleh tingkat pelapukan batuan pada kawasan tersebut. Kualitas tanah mempunyai pengaruh besar terhadap intensitas penggunaan lahannya, kawasan-kawasan yang mempunyai perkembangan lapisan tanah yang masih tipis biasa digunakan untuk kegiatan budidaya tanaman. Wilayah Makassar terdiri dari laut, dataran 
rendah dan tinggi sehingga perlu dibuatkan perioritas penggunaan lahan yang sesuai dengan tingkat perkembangan pemanfaatannya. Daerah ini termasuk daerah yang beriklim sedang/tropis. Sedangkan Daerah Jeneponto merupakan daerah pesisir pantai, tingkat kelerengan datar sampai curam. Tanah didaerah ini dibedakan atas dua yaitu tanah erosi dan tidak erosi, keadaan iklim yaitu identik dengan keadaan iklim wilayah lain yang ada di pulau Sulawesi secara keseluruhan, (Pokja AMPK, 2011)

\section{METODE PENELITIAN}

\section{A. Alat dan bahan}

Alat-alat yang digunakan adalah batang pengaduk, cawan porselin, gelas kimia (Pyrex), labu tentukur, mikropipet (Memmert), pipet volume, pipet tetes, rak tabung, sendok tanduk, spektrofotometer UV-Vis $\left(\right.$ Apel $\left.{ }^{\circledR} P D 302 U V\right)$, rotavapor $\left(I_{k a}{ }^{\circledR} R V 10\right.$ basic), tabung reaksi, timbangan analitik (Caratseries), dan vortex.

Bahan-bahan yang digunakan dalam penelitian ini antara lain, Ekstrak daun sairsak (Annona muricata L.), etanol 96\%, DPPH (1,1diphenyl-2-picrylhydrazyl), kertas saring, kuersetin, aluminium foil, tissue dan aquades.

\section{B. Prosedur penelitian}

\section{Pengambilan dan Pengolahan Sampel}

Pengambilan sampel daun sirsak (Annona muricata L.) dilakukan pada pagi hari di Mamuju Utara kota Pasangkayu, Makassar dan Jeneponto dengan cara mengambil daun yang masih segar secara manual, kemudian dibersihkan dari kotoran-kotoran yang menempel dengan menggunakan air yang mengalir dan dikeringkan dengan cara dianginanginkan tanpa sinar matahari kurang lebih 1 minggu. Sampel yang telah dikeringkan dipotong kecil-kecil dan diserbukkan dengan cara diblender.

\section{Proses Ekstraksi Sampel.}

Simplisia daun sirsak (Annona muricata L.) yang telah diserbukkan ditimbang sebanyak 50 gram, kemudian dimaserasi menggunakan pelarut etanol $96 \%$ pada suhu ruang selama 3 × 24 jam. Setelah itu, dimasukkan kedalam wadah yang tertutup rapat dan terlindung dari sinar matahari sambil di aduk. Hasil maserasi disaring, kemudian remaserasi hingga cairan berwarna bening kehijauan, lalu di rotavapor. Hasil ekstrak encer diuapkan hingga menjadi ekstrak kental.

\section{Pembuatan larutan dan pengukuran}

Pengujian antiradikal bebas pada ekstrak daun sirsak (Annona muricata L.) ekstrak etanol 96\% merujuk pada prosedur Raden Nabillah (2012).

\section{a. Pembuatan Larutan DPPH}

Larutan DPPH 100 ppm dibuat dengan cara ditimbang sebanyak $10 \mathrm{mg}$ serbuk DPPH kemudian dilarutkan dengan $100 \mathrm{~mL}$ etanol 96\% dalam labu tentukur. Konsentrasi 35 ppm dibuat dengan cara memipet 87,5 mL DPPH 100 ppm, kemudian dicukupkan volumenya hingga $250 \mathrm{~mL}$.

Pengukuran panjang gelombang maksium dilakukan dengan mengukur larutan DPPH yang telah diinkubasi selama 30 menit pada suhu $37^{\circ} \mathrm{C}$ dan diukur pada panjang gelombang 450-650 nm.

\section{b. Pembuatan larutan dan Pengukuran daya antioksidan sampel pembanding kuarsetin}

Larutan stok $10 \mathrm{ppm}$ dibuat dengan cara ditimbang $1 \mathrm{mg}$ kuersetin kemudian di larutkan dengan etanol $96 \%$ dalam labu tentukur $100 \mathrm{ml}$, setelah itu dibuat beberapa variasi konsentrasi.

Konsentrasi 1, 3, 4, 5, dan 6 ppm, dibuat dengan cara masing-masing larutan stok dipipet 1, 3, 4, 5, dan $6 \mathrm{~mL}$, lalu dicukupkan dengan etanol $96 \%$ sampai volume akhir $10 \mathrm{~mL}$.

Pengujian dilakukan dengan memipet $1 \mathrm{~mL}$ larutan sampel dari berbagai konsentrasi, kemudian masing-masing ditambahkan $4 \mathrm{~mL}$ DPPH 35 ppm. Campuran kemudian dihomogenkan dengan cara divortex dan diinkubasi pada suhu $37^{\circ} \mathrm{C}$ selama 30 menit lalu serapannya diukur pada panjang gelombang $515 \mathrm{~nm}$.

\section{c. Pembuatan larutan dan Pengukuran daya antioksidan ekstrak etanol daun sirsak (Annona muricata L.) dari tiga Daerah}

Larutan stok 100 ppm dibuat dengan cara menimbang ekstrak etanol daun sirsak (Annona muricata L.) sebanyak $10 \mathrm{mg}$ dan dilarutkan dengan etanol 96\%, larutan dihomogenkan dan dicukupkan volumenya hingga $100 \mathrm{~mL}$. Selanjutnya, pengenceran dilakukan untuk membuat beberapa variasi konsentrasi.

Ada lima variasi konsentrasi yaitu 10, 20, 30, 40 dan 50 ppm, masing-masing larutan stok dipipet 1, 2, 3, 4 dan $5 \mathrm{~mL}$ lalu dicukupkan dengan etanol $96 \%$ sampai volume akhir $10 \mathrm{~mL}$.

Pengujian dilakukan dengan memipet $1 \mathrm{~mL}$ larutan sampel dari berbagai konsentrasi, kemudian masing-masing ditambahkan $4 \mathrm{~mL}$ DPPH 35 ppm. Campuran kemudian dihomogenkan dengan cara divortex dan diinkubasi pada suhu $37^{\circ} \mathrm{C}$ selama 30 menit lalu serapannya diukur menggunakan spektrofotometer UV-Vis pada panjang gelombang $515 \mathrm{~nm}$.

\section{d. Analisis Data}

Besarnya presentase pengikat radikal bebas dihitung dengan rumus : 
$\%$ Pengikatan radikal bebas $=$

$$
\frac{(\text { Abs standar-Abs sampel) }}{\text { Abs standar }} \times 100 \%
$$

Nilai $\mathrm{IC}_{50}$ dihitung dengan menggunakan persamaan regresi linear, konsentrasi sampel sebagai sumbu $\mathrm{x}$ dan $\%$ inhibisi sebagai sumbu $\mathrm{y}$.

Dari persamaan : $\mathrm{y}=\mathrm{a}+\mathrm{bx}$ dapat dihitung nilai $\mathrm{IC}_{50}$ dengan menggunakan rumus : $\mathrm{IC}_{50}=\frac{(50-\mathrm{b})}{\mathrm{a}}$ Keterangan : $y=50$ (Penghambat $50 \%$ oksidasi)

$$
\begin{aligned}
\mathrm{x}= & \mathrm{IC}_{50} \text { (bilangan yang menunjukkan } \\
& \text { konsentrasi ekstrak yang mampu } \\
& \text { menghambat proses oksidasi sebesar } \\
& 50 \% \text { ) } \\
\mathrm{a}= & \text { slope } \\
\mathrm{b}= & \text { intercept }
\end{aligned}
$$

\section{HASIL DAN PEMBAHASAN}

\section{A. Hasil}

Tabel 1. Persen (\%) rendamen ekstrak etanol daun sirsak (Annona muricata L.) dari tiga daerah.

\begin{tabular}{ccccc}
\hline Sampel & $\begin{array}{c}\text { Berat } \\
\text { Awal } \\
(\mathrm{g})\end{array}$ & $\begin{array}{c}\text { Ekstrak } \\
(\mathrm{g})\end{array}$ & $\begin{array}{c}\text { JumLah } \\
\text { pelarut } \\
\text { etanol } \\
(\mathrm{L})\end{array}$ & $\begin{array}{c}\text { Rendamen } \\
\text { ekstrak } \\
(\%)\end{array}$ \\
\hline $\begin{array}{c}\text { Daun sirsak } \\
\text { Mamuju }\end{array}$ & 50 & 5,364 & 10 & 10,728 \\
\hline $\begin{array}{c}\text { Daun sirsak } \\
\text { Makassar }\end{array}$ & 50 & 6,115 & 12 & 12,23 \\
\hline $\begin{array}{c}\text { Daun sirsak } \\
\text { Jeneponto }\end{array}$ & 50 & 5,864 & 11 & 11,728 \\
\hline
\end{tabular}

Tabel 2. Hasil running panjang gelombang maksimum DPPH 35 ppm

\begin{tabular}{ccc}
\hline Sampel & $\begin{array}{c}\text { Panjang } \\
\text { gelombang } \\
\text { maksimum }\end{array}$ & Absorban \\
\hline $\begin{array}{c}\text { DPPH 35 } \\
\text { ppm }\end{array}$ & $515 \mathrm{~nm}$ & 0.869 \\
\hline
\end{tabular}

Tabel 3. Perhitungan $\%$ inhibisi kuersetin (Pembanding)

\begin{tabular}{cccc}
\hline $\begin{array}{c}\text { Konsentrasi } \\
(\mathbf{p p m})\end{array}$ & $\begin{array}{c}\text { Absorbansi } \\
\mathbf{( 5 1 5 )}\end{array}$ & $\begin{array}{c}\text { \% } \\
\text { Inhibisi }\end{array}$ & $\begin{array}{c}\text { IC50 } \\
(\boldsymbol{\mu g} / \mathbf{m L})\end{array}$ \\
\hline $\mathbf{1}$ & 0,549 & 36,823 & \\
$\mathbf{3}$ & 0,440 & 49,367 & 1,414 \\
$\mathbf{4}$ & 0,377 & 56,616 & \\
$\mathbf{5}$ & 0,338 & 61,104 & \\
$\mathbf{6}$ & 0,285 & 67,203 & \\
& & & \\
\hline
\end{tabular}

Tabel 4. Perhitungan \% inhibisi radikal bebas ekstrak etanol daun sirsak (Annona muricata L.) yang berasal dari Mamuju Utara

\begin{tabular}{cccc}
\hline $\begin{array}{c}\text { Konsentrasi } \\
(\mathbf{p p m})\end{array}$ & $\begin{array}{c}\text { Absorbansi } \\
\mathbf{( 5 1 5 )}\end{array}$ & $\begin{array}{c}\text { \% } \\
\text { Inhibisi }\end{array}$ & $\begin{array}{c}\mathbf{I C}_{\mathbf{5 0}} \\
(\boldsymbol{\mu} \mathbf{g} / \mathbf{m L})\end{array}$ \\
\hline $\mathbf{1 0}$ & 0,568 & 34,637 & \\
$\mathbf{2 0}$ & 0,528 & 39,240 & \\
$\mathbf{3 0}$ & 0,519 & 40,276 & 1,512 \\
$\mathbf{4 0}$ & 0,495 & 43,037 & \\
$\mathbf{5 0}$ & 0,475 & 45,339 & \\
\hline
\end{tabular}

Tabel 5. Perhitungan \% inhibisi radikal bebas ekstrak etanol daun sirsak (Annona muricata L.) yang berasal dari Makassar

\begin{tabular}{cccc}
\hline $\begin{array}{c}\text { Konsentrasi } \\
(\mathbf{p p m})\end{array}$ & $\begin{array}{c}\text { Absorbansi } \\
\mathbf{( 5 1 5 )}\end{array}$ & $\begin{array}{c}\text { \% } \\
\text { Inhibisi }\end{array}$ & $\begin{array}{c}\mathbf{I C}_{\mathbf{5 0}} \\
(\boldsymbol{\mu g} / \mathbf{m L})\end{array}$ \\
\hline $\mathbf{1 0}$ & 0,518 & 40,391 & \\
$\mathbf{2 0}$ & 0,486 & 44,073 & \\
$\mathbf{3 0}$ & 0,460 & 47,065 & 1,380 \\
$\mathbf{4 0}$ & 0,411 & 52,704 & \\
$\mathbf{5 0}$ & 0,381 & 56,156 & \\
\hline
\end{tabular}

Tabel 6. Perhitungan \% inhibisi radikal bebas ekstrak etanol daun sirsak (Annona muricata L.) yang berasal dari Jeneponto

\begin{tabular}{cccc}
\hline $\begin{array}{c}\text { Konsentrasi } \\
(\mathbf{p p m})\end{array}$ & $\begin{array}{c}\text { Absorbansi } \\
(\mathbf{5 1 5})\end{array}$ & $\begin{array}{c}\text { \% } \\
\text { Inhibisi }\end{array}$ & $\begin{array}{c}\text { IC } \mathbf{5 0}_{\mathbf{H}} \\
(\boldsymbol{\mu g} / \mathbf{m L})\end{array}$ \\
\hline $\mathbf{1 0}$ & 0,543 & 37,514 & \\
$\mathbf{2 0}$ & 0,531 & 38,895 & 1,420 \\
$\mathbf{3 0}$ & 0,510 & 41,311 & \\
$\mathbf{4 0}$ & 0,489 & 43,728 & \\
$\mathbf{5 0}$ & 0,472 & 45,684 & \\
& & & \\
\hline
\end{tabular}

\section{B. Pembahasan}

Antioksidan merupakan komponen penting yang terkandung dalam tumbuhan. Antioksidan dapat meredam dan merangkal radikal bebas dengan mendonorkan elektronnya dan dapat mencegah reaksi berantai yang ditimbulkan radikal bebas.

Secara biologi pengertian antioksidan adalah senyawa yang mampu menangkal atau meredam dampak negatif oksidan dalam tubuh. Penelitian ini menggunakan daun sirsak (Annona muricata L.) yang diambil dari tiga daerah yaitu daerah Mamuju Utara, Makassar, dan Jeneponto.

Pengambilan sampel daun sirsak (Annona muricata L.) dilakukan pada pagi hari di daerah Mamuju Utara, Makassar, dan Jeneponto dengan cara mengambil daun yang masih segar secara manual, kemudian dibersihkan dari kotoran-kotoran yang 
menempel dengan menggunakan air yang mengalir dan dikeringkan dengan cara diangin-anginkan tanpa sinar matahari kurang lebih 1 minggu.

Daun sirsak (Annona muricata L.) dari tiga daerah tersebut diekstraksi menggunakan metode maserasi. Metode ini dipilih karena merupakan metode ekstraksi yang sederhana serta dapat menarik komponen kimia yang terdapat pada sampel tanpa merusak senyawanya. Adapun pelarut yang digunakan pada proses maserasi yaitu etanol 96\%, digunakan pelarut etanol karena sifatnya yang mampu melarutkan hampir semua zat-zat baik yang bersifat polar, semipolar dan nonpolar serta kemampuannya untuk mengendapkan protein dan menghambat kerja enzim sehingga dapat terhindar proses hidrolisis dan oksidasi (Rizka Aulia rahma, 2012).

Pengujian aktivitas antioksidan dengan metode DPPH dipilih karena metode ini sederhana, mudah, cepat dan peka serta sampel yang digunakan hanya sedikit. Pengerjaan penelitian ini merujuk pada prosedur (Raden nabilah, 2012). Dimana pengukuran absorbansi sampel pada spektrofotometri UV-Vis dengan panjang gelombang $515 \mathrm{~nm}$ dengan volume sampel yang digunakan $1 \mathrm{~mL}$ dan DPPH sebanyak 4 $\mathrm{mL}$. Adapun konsetrasi sampel yang digunakan adalah 10, 20, 30, 40, dan 50 ppm untuk semua variasi sampel, sedangkan konsentrasi pembanding adalah, 1, 3, 4, 5 dan 6 ppm. Dimana pembanding yang digunakan sebagai kontrol positif adalah kuersetin.

Setelah dilakukan pengerjaan dan pengukuran, dilakukan perhitungan persen (\%) inhibisi dan $\mathrm{IC}_{50}$ antiradikal bebas dari ekstrak etanol daun sirsak (Annona muricata L.) persen inhibisi adalah kemampuan suatu bahan untuk menghambat aktivitas radikal bebas yang berhubungan dengan konsentarasi suatu sampel, sedangkan $\mathrm{IC}_{50}$ merupakan salah satu parameter yang digunakan untuk menginterprestasikan hasil dari pengujian $\mathrm{DPPH}$, semakin rendah nilai $\mathrm{IC}_{50}$ dari suatu sampel maka kemampuan sebagai antioksidan semakin besar.

Suatu senyawa dinyatakan sebagai antiradikal bebas sangat kuat apabila nilai $\mathrm{IC}_{50}<10$ $\mu \mathrm{g} / \mathrm{mL}$, kuat apabila nilai $\mathrm{IC}_{50}$ antara $10-50 \mu \mathrm{g} / \mathrm{mL}$, sedang apabila nilai $\mathrm{IC}_{50}$ berkisar antara 50-100 $\mu \mathrm{g} / \mathrm{mL}$, lemah apabila nilai $\mathrm{IC}_{50}$ berkisar antar 100$250 \mu \mathrm{g} / \mathrm{mL}$ dan dinyatakan tidak aktif apabilla nilai $\mathrm{IC}_{50} 250 \mu \mathrm{g} / \mathrm{mL}$. ekstrak etanol daun sirsak (Annona muricata L.) memiliki aktivitas antioksidan.

Hasil yang diperoleh pada pengujian aktivitas antioksidan ekstrak etanol daun sirsak (Annona muricata L.) adalah sampel yang berasal dari Mamuju Utara memiliki nilai $\mathrm{IC}_{50} 1,512 \mu \mathrm{g} / \mathrm{mL}$ merupakan antioksidan yang sangat kuat, sampel yang berasal dari Makassar memiliki nilai $\mathrm{IC}_{50}$ 1,380 $\mu \mathrm{g} / \mathrm{mL}$ merupakan antioksidan yang sangat kuat dan sampel yang berasal dari Jeneponto memiliki nilai $\mathrm{IC}_{50} 1,420 \mu \mathrm{g} / \mathrm{mL}$ juga merupakan antioksidan yang sangat kuat. Sedangkan pada pengukuran larutan standar kuersetin (pembanding) memiliki nilai $\mathrm{IC}_{50}$ $1,414 \mu \mathrm{g} / \mathrm{mL}$ dan merupakan antioksidan yang sangat kuat. Dari hasil pengujian yang telah dilakukan, dapat diketahui bahwa aktivitas antioksidan pada sampel daun sirsak (Annona muricata L.) yang berasal dari daerah Makassar memiliki tingkat dan potensi aktivitas antioksidan yang lebih kuat dibandingkan dengan kuersetin (pembanding) karena nilai $\mathrm{IC}_{50}$ yang didapatkan lebih rendah.

Dari ketiga daerah, masing-masing sampel yang digunakan memiliki tingkat aktivitas antioksidan yang berbeda-beda. Hal yang dapat mempengaruhi kadar suatu senyawa dalam tanaman diantaranya adalah letak geografis tanaman, faktor iklim yang meliputi suhu, udara dan kelembaban, faktor esensial seperti cahaya, air, dan unsur hara tanah. Serta faktor gangguan hama atau penyakit dan gulma.

\section{KESIMPULAN}

Berdasarkan hasil penelitian yang dilakukan dapat disimpulakan bahwa:

1. Perbandingan aktivitas antioksidan ekstrak etanol daun sirsak (Annona muricata L.) yang berasal dari tiga daerah yaitu daerah Mamuju Utara, Makassar dan Jeneponto masing-masing memiliki aktivitas antioksidan yang sangat kuat.

2. Ekstrak etanol daun sirsak (Annona muricata L.) yang berasal dari tiga daerah memiliki potensi aktivitas antioksidan yang berbeda-beda, sampel yang berasal dari daerah Mamuju Utara memiliki nilai $\mathrm{IC}_{50} 1,512 \mu \mathrm{g} / \mathrm{mL}$, Makassar memiliki nilai $\mathrm{IC}_{50} 1,380 \mu \mathrm{g} / \mathrm{mL}$ dan Jeneponto memiliki nilai $\mathrm{IC}_{50} 1,420 \mu \mathrm{g} / \mathrm{mL}$.

\section{DAFTAR PUSTAKA}

Haryati, S., 2005, Standarisasi Ekstrak Tumbuhan Obat Indonesia salah satu Tahapan Penting dalam Pengembangan Obat Asli Indonesia, info POM.

Pokja AMPL., 2011, Buku Putih Sanitasi Daerah., diakses pada 11 Februari 2016, <www://ampl.or.id/50114/overview>.

Putri, N. R. A., 2012, 'Uji aktivitas antioksidan ektrak etanol daun sirsak (Annona muricata L.) dengan metode DPPH (1,1-Diphenyl2picrylhydrazil)', Skripsi, S.ked, Fakultas Kedokteran dan Ilmu Kesehatan, Universitas Islam Negeri, Jakarta 
Radi, J., 2002, Sirsak Budaya dan Pemanfaatannya, Kunisius, Jakarta, Indonesia.

Rahma, A., 2012, Etanol., diakses pada 19 Oktober2015,

$<$ http://www.rizkaauliarahma.wordpress.co m>.

Sidik, 1997, Antioksidan Alami Asal Tumbuhan, Seminar nasional tumbuhan obat Indonesia XII 26-27 juni 1997., diakses pada 19 Oktober 2015, <www.repository.maranatha.edu/2013 $>$.

Suharyadi, A., 2014, Pengaruh Pemberian Ekstrak Etanol Daun Sirsak Terhadap Gambaran Histopatologi Ginjal Tikus yang Diinduksi $D M B A$, Universitas Lampung, Indonesia.

Zuhud, E., 2011, Bukti Kedahsyatan Sirsak Menupas Kanker, Agromedia, Jakarta Selatan, Indonesia. 